\title{
THE
}

1994

\section{Symptoms of Nitrogen Saturation in a Riparian Wetland}

Gay C. Hanson

University of Rhode Island

Peter M. Groffman

Arthur J. Gold

University of Rhode Island, agold@uri.edu

Follow this and additional works at: https://digitalcommons.uri.edu/nrs_facpubs

Terms of Use

All rights reserved under copyright.

\section{Citation/Publisher Attribution}

Hanson, G. C., Groffman, P. M. and Gold, A. J. (1994), Symptoms of Nitrogen Saturation in a Riparian Wetland. Ecological Applications, 4: 750-756. doi:10.2307/1942005.

Available at: https://doi.org/10.2307/1942005

This Article is brought to you for free and open access by the Natural Resources Science at DigitalCommons@URI. It has been accepted for inclusion in Natural Resources Science Faculty Publications by an authorized administrator of DigitalCommons@URI. For more information, please contact digitalcommons-group@uri.edu. 


\title{
SYMPTOMS OF NITROGEN SATURATION IN A RIPARIAN WETLAND ${ }^{1}$
}

\author{
Gay C. Hanson \\ University of Rhode Island, Department of Natural Resources Science, \\ Kingston, Rhode Island 02881 USA \\ Peter M. GRoFFMAN ${ }^{2}$ \\ Institute of Ecosystem Studies, Box AB, Millbrook, New York 12545 USA \\ Arthur J. Gold \\ University of Rhode Island, Department of Natural Resources Science, \\ Kingston, Rhode Island 02881 USA
}

\begin{abstract}
Riparian forests are in a unique position in the landscape since they form a transition between uplands and aquatic systems. These ecosystems may be highly susceptible to nitrogen $(\mathrm{N})$ saturation since they may be subject to high inputs of $\mathrm{N}$ from upland areas. We measured potential net $\mathrm{N}$ mineralization and nitrification, soil inorganic $\mathrm{N}$ levels, microbial biomass carbon (C) and $\mathbf{N}$ content, and the $\mathbf{N}$ content of litter as indicators of $\mathrm{N}$ saturation in two riparian zones on the eastern and western sides of a stream. The sites had similar soils, vegetation, and hydrology, but differing upland land use. The eastern or "enriched" site was downgradient of a dense residential housing development (built in the 1950s) that produced high groundwater nitrate $\left(\mathrm{NO}_{3}{ }^{-}\right.$) concentrations. The western or "control" site had an undeveloped upland. Our objectives were (1) to evaluate if groundwater $\mathrm{NO}_{3}{ }^{-}$loading had induced changes in surface soil $\mathrm{N}$-cycle processes that are symptoms of $\mathrm{N}$ saturation in the enriched site and (2) to evaluate these changes in relation to inputs and outputs of $\mathbf{N}$ to the site. Soil inorganic- $\mathbf{N}$ levels, litter $\mathbf{N}$ content, and potential net $\mathrm{N}$ mineralization and nitrification were significantly higher on the enriched site relative to the control site, suggesting that the enriched site was $N$ saturated. However, input-output analysis indicated that the enriched site was still a sink for uplandderived $\mathrm{NO}_{3}{ }^{-}$. High rates of denitrification and storage of $\mathrm{N}$ in soil organic matter appear to moderate $\mathrm{N}$ saturation on the enriched site.
\end{abstract}

Key words: denitrification; forest nutrient cycling; groundwater nitrate; microbial biomass; mineralization; nitrification; nitrogen saturation; riparian forests; wetlands.

\section{INTRODUCTION}

Nitrogen $(\mathrm{N})$ is generally considered to be the primary factor limiting production in forest ecosystems (Vitousek and Howarth 1991). However, some studies suggest that forest systems have been receiving $\mathrm{N}$ additions in excess of their needs and that losses of $\mathrm{N}$ from these systems are occurring (Friedland et al. 1984, Nihlgard 1985, Rascher et al. 1987). Nitrogen "saturation" has been defined as the availability of ammonium $\left(\mathrm{NH}_{4}{ }^{+}\right)$and nitrate $\left(\mathrm{NO}_{3}{ }^{-}\right)$in excess of the demand for plant and microbial nutrition (Aber et al. 1989). An ecosystem that is saturated with $N$ will not retain $\mathrm{N}$ from external sources.

Symptoms of $\mathrm{N}$ saturation that may be seen in an ecosystem include increased rates of nitrification in soils, increased $\mathrm{N}$ leaching to groundwater, lowered resistance of plants to pests and pathogens, increased frost damage, and species composition changes (Aber

\footnotetext{
${ }^{1}$ Manuscript received 18 August 1993; revised and accepted 8 December 1993.

${ }_{2}$ Address correspondence and/or reprint requests to this author.
}

et al. 1989, Johnson and Ball 1990, Skeffington 1990). Nitrogen saturation may also be linked to acidification of soils and aluminum mobilization into groundwater (McNulty et al. 1990). However, a forest system may receive high inputs of $\mathrm{N}$ and show little or no symptoms of saturation if sufficient denitrification, plant uptake, or storage of $\mathrm{N}$ in organic matter are occurring (Aber et al. 1989). The effects of $\mathrm{N}$ saturation on a particular ecosystem are dependent on the vegetation present, site history, the $C: N$ ratio of the soil organic matter, and the nature and extent of external $\mathrm{N}$ inputs (Brown et al. 1988).

Riparian forests are in a unique position in the landscape since they form a transition between uplands and aquatic systems. These ecosystems may be highly susceptible to $\mathrm{N}$ saturation since they may be subject to high inputs of $\mathrm{N}$ from upland areas. Riparian wetlands potentially act as filters for much of the water draining from upland sources and have been found to be important regulators of water quality in agricultural watersheds (Lowrance et al. 1984, Peterjohn and Correll 1984, Jacobs and Gilliam 1985).

In this study two riparian forests were evaluated for 


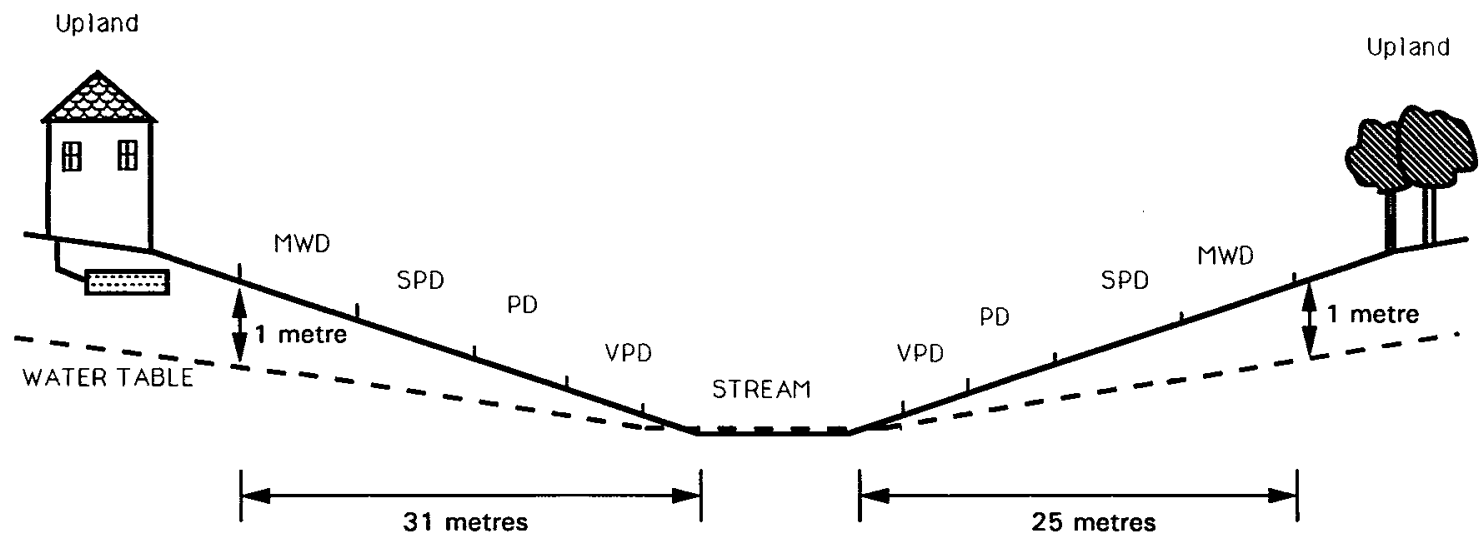

FIG. 1. Site diagram showing enriched and control sites located on eastern (left) and western (right) sides of Sand Hill Brook (Rhode Island, USA). Modified from Hanson et al. (1994). Soil drainage classes: MWD = moderately well drained, $\mathrm{SPD}=$ somewhat poorly drained, $\mathrm{PD}=$ poorly drained, $\mathrm{VPD}=$ very poorly drained.

symptoms of $\mathrm{N}$ saturation. These sites were located on opposite sides of a stream and had similar soils, vegetation and hydrology, but differing upland land use. The eastern or "enriched" site was downgradient of a dense residential housing development with on-site septic systems. The development was built in the 1950 s, so that the site had been receiving high $\mathrm{NO}_{3}{ }^{-}$loading via groundwater for a long period of time. Previous research characterized groundwater $\mathrm{NO}_{3}{ }^{-}$loading and quantified spatial and temporal patterns of $\mathrm{NO}_{3}{ }^{-}$removal from groundwater and surface soil denitrification at this site (Groffman et al. 1992, Simmons et al. 1992, Hanson et al. 1994). The western or "control" site had an undeveloped upland. The sites included riparian red maple wetlands with poorly drained and very poorly drained soils and upland-wetland transition zones with moderately well drained and somewhat poorly drained soils.

We measured potential net $\mathrm{N}$ mineralization and nitrification, soil inorganic $\mathrm{N}$ levels, microbial biomass carbon (C) and $\mathrm{N}$ content, and the $\mathrm{N}$ content of litter as indicators of $\mathrm{N}$ saturation. Our objectives were (1) to evaluate if groundwater $\mathrm{NO}_{3}-$ loading had induced changes in surface soil $\mathrm{N}$-cycle processes that are symptoms of $N$ saturation in the enriched site and (2) to evaluate these changes in relation to inputs and outputs of $\mathrm{N}$ to the site.

\section{METHODS \\ Site characterization}

The sites were located within $25 \mathrm{~km}$ of Kingston, Rhode Island, USA, on the eastern and western sides of Sand Hill Brook, a tributary of Narragansett Bay (Fig. 1). The sites were forested with oak (Quercus sp.) and maple (Acer sp.) dominant in the upland-to-wetland transition zones (moderately well drained [MWD] and somewhat poorly drained [SPD] soils) and red maple (Acer rubrum) dominant in the wetlands (poorly drained [PD] and very poorly drained [VPD] soils). Soils at both sites were derived from stratified glaciofluvial deposits with variable amounts of alluvial material and were coarse-textured inceptisols and entisols (Table 1). Soil drainage classes were delineated by a registered soil scientist. The poorly drained and very poorly drained soils at each site were classified as hydric. The eastern or "enriched" site was directly downgradient of a dense unsewered residential development that was built in the 1950s. The "control" site was located on the western side of the stream, which is downhill from an undeveloped forested upland.

\section{Soil analysis}

Soil samples $(0-15 \mathrm{~cm})$ were taken from $4 \times 8 \mathrm{~m}$ plots located within each soil type on each of the two

TABLE 1. Soil (A horizon) properties and groundwater $\mathrm{NO}_{3}{ }^{-}$ concentrations at the enriched and control sites. Data from Hanson et al. (1994).

\begin{tabular}{|c|c|c|c|c|c|}
\hline Site & $\begin{array}{c}\text { Soil } \\
\text { drainage } \\
\text { class* }\end{array}$ & $\begin{array}{c}\% \\
\text { sand }\end{array}$ & $\begin{array}{l}\% \text { soil } \\
\text { organic } \\
\text { mattert }\end{array}$ & $\mathrm{pH} \dagger$ & $\begin{array}{l}\text { Ground- } \\
\text { water } \\
\mathrm{NO}_{3}^{--} \mathrm{N} \\
(\mathrm{mg} / \mathrm{L})\end{array}$ \\
\hline Enriched & $\begin{array}{l}\text { MWD } \\
\text { SPD } \\
\text { PD } \\
\text { VPD }\end{array}$ & $\begin{array}{l}99.3 \\
99.3 \\
99.5 \\
91.8\end{array}$ & $\begin{array}{l}5.9 \ddagger \\
6.3 \ddagger \\
8.6 \ddagger \\
12.5\end{array}$ & $\begin{array}{l}3.95 \ddagger \\
3.90 \ddagger \\
4.05 \ddagger \\
5.05\end{array}$ & $\begin{array}{l}7.0 \\
2.8 \\
\\
1.6\end{array}$ \\
\hline Control & $\begin{array}{l}\text { MWD } \\
\text { SPD } \\
\text { PD } \\
\text { VPD }\end{array}$ & $\begin{array}{l}99.4 \\
99.2 \\
96.9 \\
98.0\end{array}$ & $\begin{array}{l}3.6 \\
4.9 \\
3.5 \\
3.5\end{array}$ & $\begin{array}{l}4.74 \\
4.79 \\
4.63 \\
4.97\end{array}$ & $\begin{array}{l}<0.1 \\
<0.1 \\
<0.1\end{array}$ \\
\hline
\end{tabular}

* $\mathrm{MWD}=$ moderately well drained, $\mathrm{SPD}=$ somewhat poorly drained, $\mathrm{PD}=$ poorly drained, $\mathrm{VPD}=$ very poorly drained. $\dagger$ Indicates significant difference between enriched and control site soils $(P<0.05$, one-way ANOVA).

$¥$ Enriched and control sites differ significantly for this soil type $(P<0.05$, one-way ANOVA). 
sites. Samples were taken weekly or every 2 wk during the spring and fall, and monthly during the summer for a total of 15 sampling dates between March 1991 and March 1992. Samples were held at $4^{\circ} \mathrm{C}$ between the time of sampling and analysis.

Soil moisture was measured gravimetrically. Soil inorganic $\mathrm{N}\left(\mathrm{NH}_{4}{ }^{+}\right.$and $\left.\mathrm{NO}_{3}{ }^{-}\right)$was extracted with a 2 mol/L $\mathrm{KCl}$ solution and quantified with an Alpkem RFA 300 Rapid Flow Analyzer (Alpkem Corporation, Clackamas, Oregon, USA). Soil moisture and inorganic $\mathrm{N}$ were quantified on every sample date.

Microbial biomass $\mathrm{C}$ and $\mathrm{N}$ content was quantified using the chloroform fumigation-incubation method (Jenkinson and Powlson 1976). Samples were fumigated to lyse microbial cells, inoculated with fresh soil, and incubated for $10 \mathrm{~d}$ at $25^{\circ} \mathrm{C}$ at field moisture content. Carbon dioxide $\left(\mathrm{CO}_{2}\right)$ and inorganic $\mathrm{N}$ released during the incubation were assumed to be directly proportional to the amount of $\mathrm{C}$ and $\mathrm{N}$ in the microbial biomass of the original sample. A proportionality constant $(0.45)$ was used to calculate biomass $C$ from the $\mathrm{CO}_{2}$ produced during the incubation. Carbon dioxide was measured by gas chromatography (thermal conductivity detector, Porapak $Q$ column), and inorganic $\mathrm{N}$ was quantified as described above. Microbial biomass $\mathrm{C}$ and $\mathrm{N}$ content were measured on six sample dates between March 1991 and March 1992.

Potential net $\mathrm{N}$ mineralization and nitrification were quantified as the accumulation of $\mathrm{NH}_{4}{ }^{+}$plus $\mathrm{NO}_{3}{ }^{-}$ and $\mathrm{NO}_{3}$ alone during 10-d incubations of unamended field-moist soils at $25^{\circ} \mathrm{C}$. Ammonium and $\mathrm{NO}_{3}{ }^{-}$ were quantified as described above. Potential net $\mathrm{N}$ mineralization and nitrification were measured on six sample dates between March 1991 and March 1992.

\section{Litter analysis}

Fallen leaves from three vegetation layers (trees, shrubs, herbaceous plants) were gathered from each soil type on the two sites, for a total of 20 leaves per layer. Oak and red maple litter were kept separate. The litter was gathered once midway through leaf drop in the fall of 1992. All leaves from each site were combined within their separate layers. Samples were ovendried, ground to pass a $1-\mathrm{mm}$ mesh screen in a Wiley mill, and analyzed for percentage $\mathrm{C}$ and $\mathrm{N}$ content on a Carlo-Erba CNS analyzer.

\section{Input-output analysis}

Groundwater $\mathrm{NO}_{3}$ - loading to the enriched site was estimated using hydraulic conductivity values and hydrology data from Simmons et al. (1992). Levels of $\mathrm{NO}_{3}{ }^{-}-\mathrm{N}$ in upland monitoring wells were combined with hydraulic conductivity estimates to calculate groundwater flux (in cubic metres per year per metre) and $\mathrm{NO}_{3}{ }^{-} \mathrm{N}$ loading (in grams per year per metre) across a $1 \mathrm{~m}$ width of interface between the riparian zone and the upland (Fig. 2). These calculations were based on shallow $(1 \mathrm{~m})$ well data and do not account for the possibility of groundwater upwelling in the interior of the riparian zone. If upwelling of $\mathrm{NO}_{3}{ }^{-}$-rich groundwater occurred, our loading values would be underestimates. Our calculation also does not account for water bypassing the forest and upwelling directly into the stream. This water has no opportunity to interact with the surface riparian ecosystem.

To identify the fates of the extra $\mathrm{N}$ that entered the enriched site via groundwater, we calculated how much "induced" or "extra" denitrification, inorganic $N$, soil organic $\mathrm{N}$, microbial biomass $\mathrm{N}$, and soil $\mathrm{NO}_{3}{ }^{-}$were present in each soil type in a $1 \mathrm{~m}$ wide by $31 \mathrm{~m}$ long by $15 \mathrm{~cm}$ deep "flow tube" through the riparian zone on the enriched site (Fig. 2). The flow tube was restricted to the surface $15 \mathrm{~cm}$ because we were analyzing the effects of groundwater $\mathrm{NO}_{3}-$ loading on surface soil processes, sampled to a depth of $15 \mathrm{~cm}$. These calculations were made by subtracting levels of these variables for the control site from the values for the enriched site on a soil-by-soil basis. These results were then multiplied by the length of each soil drainage class within the flow tube and the sum was the total "induced" for the entire $31 \mathrm{~m}$ enriched site riparian zone (Fig. 2). Denitrification values were taken from Hanson et al. (1994). We feel that it is important to subtract the "control" values from the enriched values so that we do not overestimate the effects of $\mathrm{N}$ enrichment on $\mathrm{N}$-cycle processes in the riparian zone.

\section{Statistical analysis}

Results were analyzed by one-way analysis of variance, except for soil $\mathrm{NO}_{3}{ }^{-}$data, which were not normally distributed. These data were analyzed by nonparametric (Wilcoxon, Kruskal-Wallis) statistical comparison tests (SAS 1985). Both overall site as well as soil-by-soil comparisons of the enriched and control sites were performed.

\section{RESUltS}

Soil $\mathrm{NO}_{3}-$ levels were higher $(P<0.01)$ on the enriched site over all soils and in each soil drainage class in a soil-by-soil analysis (Fig. 3). Total inorganic $\mathbf{N}$ $\left(\mathrm{NH}_{4}{ }^{+}\right.$plus $\left.\mathrm{NO}_{3}{ }^{-}\right)$in soils was higher on the enriched site overall $(P<0.01)$, and in the moderately well drained (MWD), somewhat poorly drained (SPD) $(P$ $<0.01$ ), and poorly drained (PD) soils $(P<0.10)$ on a soil-by-soil basis (Fig. 4). Potential net $N$ mineralization was higher on the enriched site overall $(P<$ $0.01)$ and in MWD and PD soils $(P<0.10)$ on a soilby-soil basis (Fig. 5). Potential net nitrification was higher $(P<0.01)$ on the enriched site over all soils, and in the MWD, SPD, and PD soils $(P<0.01)$ on a soil-by-soil basis (Fig. 6).

Nitrogen concentrations in litter were higher in most of the vegetational layers on the enriched site (Fig. 7), but the difference was significant in the red maple ( $P$ $<0.01)$ and herbaceous layers $(P<0.01)$ only. Nitrogen concentrations in litter from the shrub layer were 


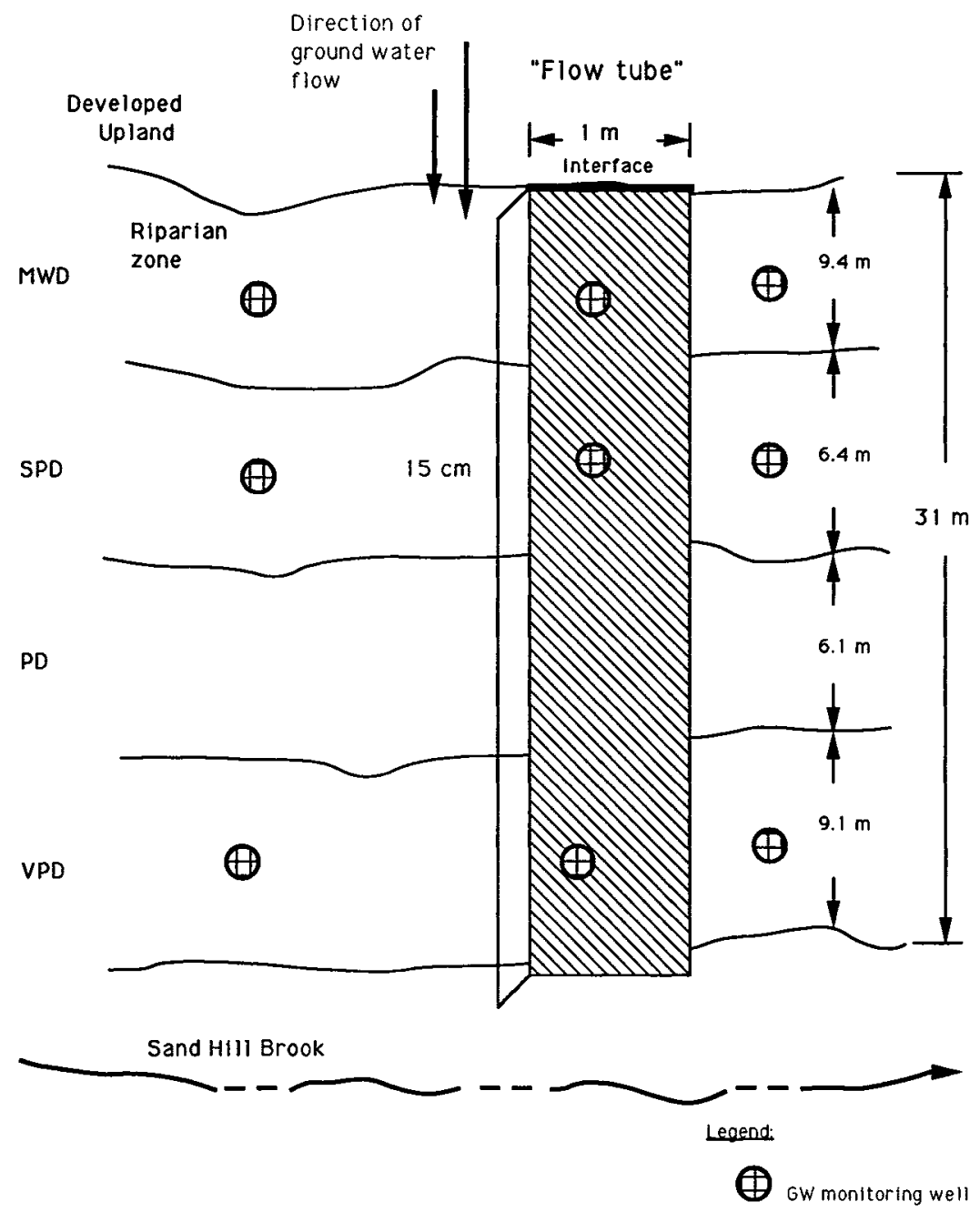

Fig. 2. Top view of the riparian zone on the enriched site showing hypothetical "flow tube" of $1 \mathrm{~m}$ width $\times 31 \mathrm{~m}$ length $\times 15 \mathrm{~cm}$ depth between the upland edge and the stream. Abbreviations as in Fig. 1 .

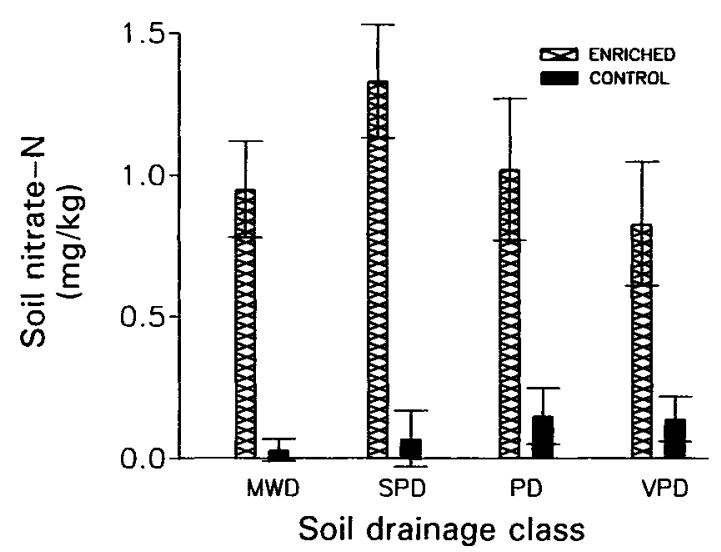

Fig. 3. Soil $\mathrm{NO}_{3}$ - levels over 15 sampling dates between March 1991 and March 1992 in four soil drainage classes in enriched and control sites. Values are mean \pm 1 SE. Abbreviations as in Fig. 1.

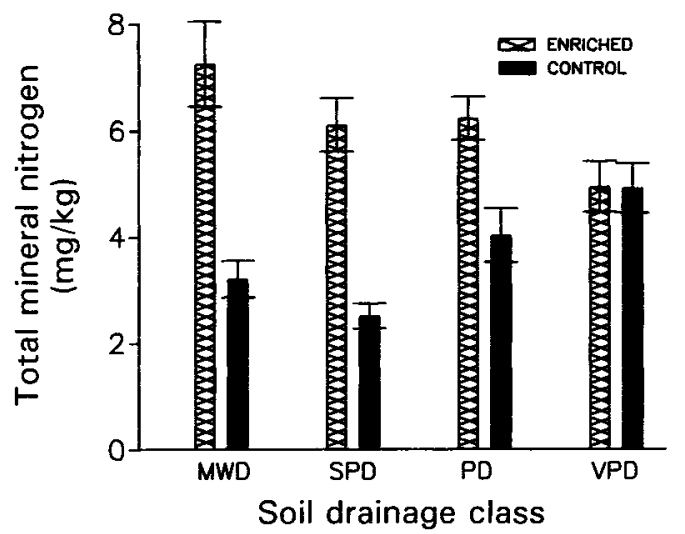

Fig. 4. Soil inorganic $\mathrm{N}\left(\mathrm{NH}_{4}{ }^{+}\right.$plus $\left.\mathrm{NO}_{3}{ }^{-}\right)$levels over 15 sampling dates between March 1991 and March 1992 in four soil drainage classes in enriched and control sites. Values are mean \pm 1 SE. Abbreviations as in Fig. 1 . 


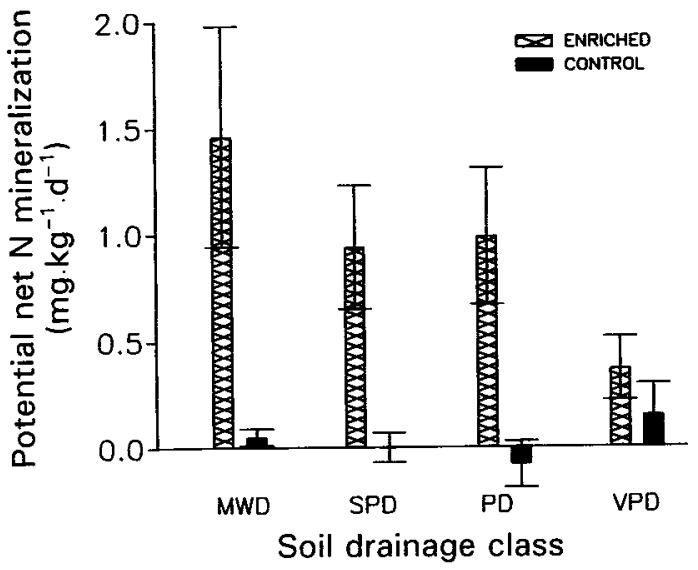

Fig. 5. Potential net $\mathbf{N}$ mineralization over six sampling dates between March 1991 and March 1992 in four soil drainage classes in enriched and control sites. Values are mean \pm 1 SE. Abbreviations as in Fig. 1.

higher $(P<0.05)$ on the control site than the enriched site.

Microbial biomass C (Fig. 8) and N (Fig. 9) content were not significantly different between sites in any soil drainage class, although in an overall analysis microbial biomass $\mathrm{N}$ was significantly higher $(P<0.05)$ on the enriched site.

Groundwater $\mathrm{N}$ loading to the enriched site was estimated as $62.7 \mathrm{~g} / \mathrm{m}$ of soil interface between the upland and riparian zone per year (Table 2). Nearly half of this input could be accounted for by "extra" or "induced" denitrification (enriched site denitrification minus control site denitrification). Large amounts of extra $\mathbf{N}$ were found in soil inorganic and organic $\mathbf{N}$ pools, while microbial biomass $\mathrm{N}$ did not appear to be a major sink for extra $\mathbf{N}$. Storage of $\mathbf{N}$ in vegetation is not known. Data from Simmons et al. (1992) suggest that losses of $\mathbf{N}$ in runoff or groundwater throughput from the enriched site were small.

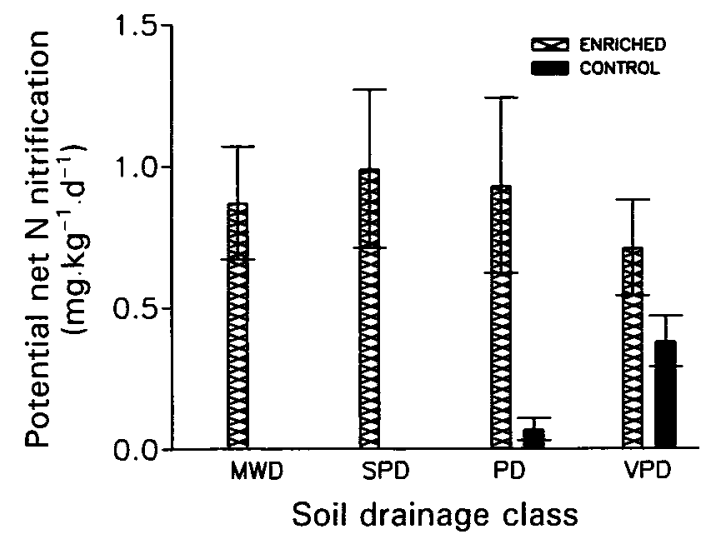

Fig. 6. Potential net nitrification over six sampling dates between March 1991 and March 1992 in four soil drainage classes in enriched and control sites. Values are mean $\pm 1 \mathrm{SE}$. Abbreviations as in Fig. 1.

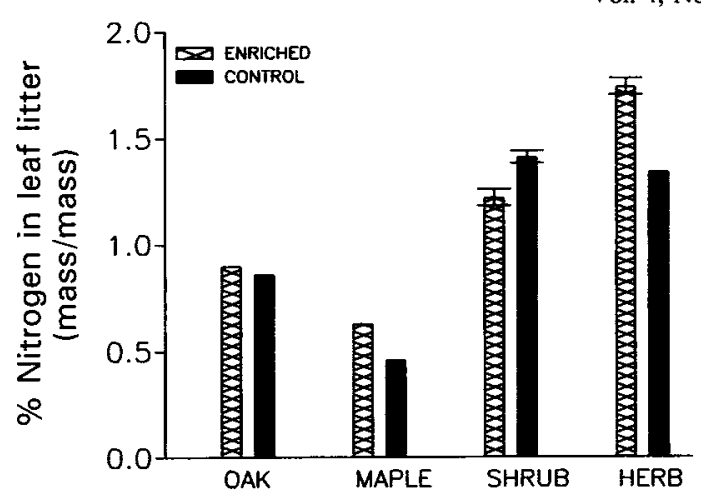

Fig. 7. Percentage $\mathrm{N}$ in litter in different vegetation layers in enriched and control sites, September 1992. Values are mean $\pm 1 \mathrm{SE}$.

\section{DISCUSSION}

The enriched site is clearly showing signs of $\mathrm{N}$ saturation. Soil and groundwater $\mathrm{NO}_{3}{ }^{-}$levels and rates of potential net $\mathrm{N}$ mineralization and nitrification were all increased on the enriched site relative to the control site. The fact that the surface soils on the enriched site showed significantly higher levels of $\mathrm{N}$-cycling processes than the soils in the control site was somewhat surprising since the $\mathrm{N}$ loading to the site was from subsurface septic systems. We hypothesize that the $\mathrm{NO}_{3}{ }^{-}$in groundwater was taken up by plants and incorporated into plant tissue. Roots were observed in the groundwater in all soil drainage classes on the enriched site (Simmons et al. 1992). When litterfall occurred, the litter from the enriched site was higher in $\mathrm{N}$ than the litter from the control site. This $\mathrm{N}$-rich litter decomposed relatively rapidly, stimulating rates of mineralization, nitrification, and denitrification ( $\mathrm{Vi}$ tousek et al. 1982, Pastor et al. 1984, Zak et al. 1986).

These results suggest that the water quality maintenance function of these riparian zones depends on a

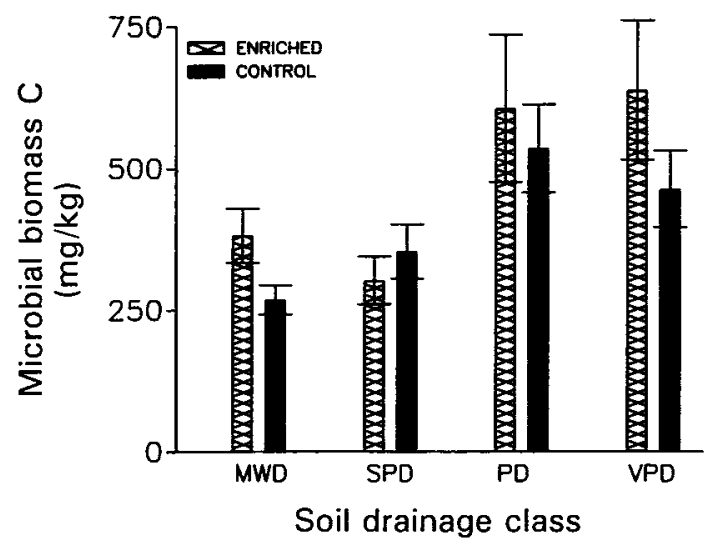

FIG. 8. Microbial biomass $\mathrm{C}$ content over six sampling dates between March 1991 and March 1992 in four soil drainage classes in enriched and control sites. Values are mean \pm 1 SE. Abbreviations as in Fig. 1. 
complex interaction among groundwater, vegetation, and surface soil microbial processes (Lowrance 1992, Hanson et al. 1994). There is a strong need to quantify just how much water and $\mathrm{NO}_{3}{ }^{-}$are removed from groundwater by riparian forest trees (Dawson and Ehleringer 1991) and for tracing the fate of this $\mathrm{NO}_{3}{ }^{-}$as it moves through the riparian ecosystem. There is also a strong need to evaluate mechanisms of subsurface $\mathrm{NO}_{3}{ }^{-}$removal during the dormant season, when plant uptake cannot be invoked as a removal mechanism.

While comparing one enriched site with one control site is not as ideal a test of the effects of enrichment as would be a comparison of several enriched vs. several non-enriched sites, the comparison here is still useful for addressing questions about $\mathrm{N}$ enrichment. The study was initiated because data from previous studies of microbial $\mathrm{N}$ cycling in a range of mostly unenriched forest sites suggested that the enriched site used here had much higher soil $\mathrm{NO}_{3}{ }^{-}$concentrations and potential net $\mathrm{N}$ mineralization and nitrification rates than similar forest soils (Groffman et al. 1991, 1992, Simmons et al. 1992). The enriched site was clearly outside the range of variation of unenriched forests in our area while the control site had levels of $\mathrm{N}$-cycling variables similar to other non-enriched sites that we have studied. Moreover, we located the control site directly opposite to the enriched site to match soils, vegetation, climate, and land use history as closely as possible.

Despite symptoms of $\mathrm{N}$ saturation induced by $30 \mathrm{yr}$ of chronic $\mathrm{N}$ loading to the enriched site, three lines of reasoning suggest that this site is still retaining $\mathrm{N}$. First, in the previous groundwater study conducted on the enriched site, Simmons et al. (1992) added known amounts of $\mathrm{NO}_{3}{ }^{-}$and conservative tracers to groundwater entering the riparian zone. They observed $>90 \%$ removal of $\mathrm{NO}_{3}{ }^{-}$by the poorly drained (PD) and very poorly drained (VPD) soils during both growing and dormant seasons. Second, in both the Simmons et al.

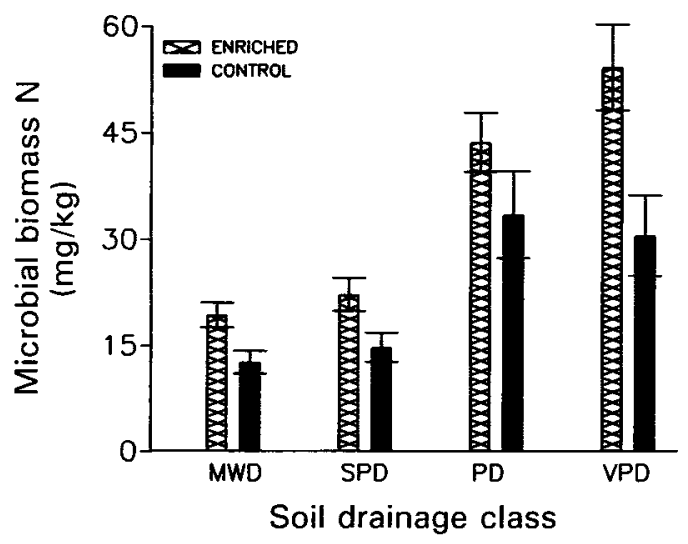

Fig. 9. Microbial biomass $\mathrm{N}$ content over six sampling dates between March 1991 and March 1992 in four soil drainage classes in enriched and control sites. Values are mean \pm 1 SE. Abbreviations as in Fig. 1.
TABLE 2. Excess inputs, outputs, and pools of $\mathrm{N}$ in a $1 \mathrm{~m}$ width of riparian zone from the upland edge to the streamside ( $1 \mathrm{~m}$ wide $\times 31 \mathrm{~m}$ long $\times 15 \mathrm{~cm}$ deep). Outputs and pool terms are $\mathrm{N}$ in the enriched site minus $\mathrm{N}$ in the control site; inputs are in the top $1 \mathrm{~m}$ of groundwater.

\begin{tabular}{lc}
\hline \hline Inputs $\left(\mathrm{g} \cdot \mathrm{m}^{-1} \cdot \mathrm{yr}^{-1}\right)$ & \\
Groundwater $\mathrm{NO}_{3}-$ input* & 63 \\
Outputs $\left(\mathrm{g} \cdot \mathrm{m}^{-1} \cdot[31 \mathrm{~m}]^{-1} \cdot \mathrm{yr}^{-1}\right.$ ) & or (grams per flow tube \\
volume per year) & 37 \\
Denitrification $\dagger$ & small \\
Hydrologic exports* & 66 \\
Pools $\ddagger\left(\mathrm{g} \cdot \mathrm{m}^{-1} \cdot[31 \mathrm{~m}]^{-1}\right.$ ) or (grams per flow tube volume) \\
Inorganic $\mathrm{N}$ & $<1$ \\
Microbial biomass & 177 \\
Soil total N & $?$ \\
Vegetation & \\
\hline
\end{tabular}

* Data from Simmons et al. (1992) used as described in Methods: Input-output analysis.

+ Data from Hanson et al. (1994).

$¥$ Data are from this study, used as described in Methods: Input-output analysis.

(1992) study and this study, groundwater $\mathrm{NO}_{3}{ }^{-}$concentrations were high in the moderately well drained (MWD) soils (2.1-15 mg/L) and were low in the VPD soils $(0.8-1.5 \mathrm{mg} / \mathrm{L})$, suggesting that $\mathrm{NO}_{3}{ }^{-}$was being consumed as groundwater moved through the riparian zone. Finally, $\mathrm{NO}_{3}-$ concentrations in shallow wells at the enriched site were consistently low (P. M. Groffman and A. J. Gold, unpublished data). These wells primarily sample water that has percolated through the soil profile. Low $\mathrm{NO}_{3}-$ concentrations in these wells suggest that excess $\mathrm{N}$ in surface soils was not leaching through the soil profile. These findings indicate that, despite long-term loading, the riparian zone on the enriched site is still filtering $\mathrm{NO}_{3}{ }^{-}$from through-flowing groundwater before it reaches the stream.

The input, output, and storage analysis suggests that storage of $\mathrm{N}$ in soil organic matter and high rates of denitrification may moderate $\mathrm{N}$ saturation on the enriched site. Increases in soil total $\mathrm{N}$ were facilitated by increases in soil organic matter, which were likely a product of increased plant production, which in turn may have been a function of nutrient loading (Paul and Clark 1989, Malkonen 1990). Much of this stored soil total N may be in "passive" soil organic matter pools that turn over slowly and are not susceptible to hydrologic losses (Paul and Clark 1989). Storage of $\mathbf{N}$ in woody tissue may be an additional long-term sink for $\mathrm{N}$ in the enriched site riparian zone (Lowrance et al. 1984). Denitrification may play a key role in buffering $\mathrm{N}$ inputs to this site, removing more than half of the annual groundwater inputs (Hanson et al. 1994). Interestingly, neither microbial biomass $\mathrm{C}$ nor $\mathrm{N}$ were much higher in the soils on the enriched site. This suggests that the microbial population was not acting as a major storage mechanism for $\mathrm{N}$, but rather was serving as a conduit through which $\mathrm{N}$ was moving.

The most dramatic signs of $\mathrm{NO}_{3}{ }^{-}$enrichment were 
found in the MWD and somewhat poorly drained (SPD) soils on the enriched site. This may be because nitrification, which results in $\mathrm{NO}_{3}{ }^{-}$as its end product, is an aerobic process, and these are the drier and hence more aerobic soil drainage classes. These soils are also physically closest to the upland source of $\mathrm{N}$ loading. Lowrance (1992) and Haycock and Pinay (1993) observed that the majority of upland-derived $\mathrm{NO}_{3}{ }^{-}$removal occurred in the first $5 \mathrm{~m}$ of riparian forests in the Southeastern United States coastal plain and in Great Britain. These results suggest that soils that are transitional between uplands and wetlands (e.g., MWD and SPD) may contribute significantly to the water quality maintenance value of riparian zones.

Groundwater nitrate loading may eventually lead to major changes in the riparian ecosystem at the enriched site. In wetlands where plants are adapted to low nutrient availability, higher $\mathrm{N}$ availability can lead to changes in plant community composition. Kadlec and Bevis (1990) studied a wetland in Michigan that had been receiving sewage effluent for $25 \mathrm{yr}$. While this wetland was still effectively filtering $\mathbf{N}$ from the effluent, phosphorus $(P)$ was no longer being retained, and the plant community had changed from a spruce-sedgeleatherleaf peatland to a pure stand of cattail, with important implications for the habitat function of the wetland. Similar changes may occur in the plant community of the riparian zone of our enriched site. These changes may be fostered by the decreases in soil $\mathrm{pH}$ that have already occurred at this site and may lead to a decrease in the water quality maintenance or habitat functions at the site.

\section{ACKNOWLEDGMENTS}

The authors thank Michael Bechdol for help with groundwater loading calculations. This research was supported by the Rhode Island Agricultural Experiment Station (Journal Article 2956) and the Andrew W. Mellon Foundation.

\section{LITERATURE Cited}

Aber, J. D., K. J. Nadelhoffer, P. Steudler, and J. M. Melillo. 1989. Nitrogen saturation in northern forest ecosystems. BioScience 39:378-386.

Brown, K. A., P. H. Freer-Smith, G. D. Howells, R. A. Skeffington, and R. B. Wilson. 1988. Rapporteurs' report on discussions at the workshop on excess nitrogen deposition, Leatherhead, September, 1987. Environmental Pollution 54:285-295.

Dawson, T. E., and J. R. Ehleringer. 1991. Streamside trees that do not use stream water. Nature 350:335-337.

Friedland, A. J., R. A. Gregory, L. Karenlampi, and A. H. Johnson. 1984. Winter damage as a factor in red spruce decline. Canadian Journal of Forest Resources 14:963-965.

Groffman, P. M., E. A. Axelrod, J. L. Lemunyon, and W. M. Sullivan. 1991. Denitrification in grass and forest vegetated filter strips. Journal of Environmental Quality 20: 671-674.

Groffman, P. M., A. J. Gold, and R. C. Simmons. 1992. Nitrate dynamics in riparian forests: microbial studies. Journal of Environmental Quality 21:666-671.
Hanson, G. C., P. M. Groffman, and A. J. Gold. 1994. Denitrification in a riparian wetland: effects of groundwater nitrate inputs. Journal of Environmental Quality 23, in press.

Haycock, N. E., and G. Pinay. 1993. Groundwater nitrate dynamics in grass and poplar vegetated riparian buffer strips during the winter. Journal of Environmental Quality 22: 273-278.

Jacobs, T. C., and J. W. Gilliam. 1985. Riparian losses of nitrate from agricultural drainage waters. Journal of Environmental Quality 14:472-478.

Jenkinson, D. S., and D. S. Powlson. 1976. The effects of biocidal treatments on metabolism of soil. V. A method for measuring soil biomass. Soil Biology and Biochemistry 8:209-213.

Johnson, D. W., and J. T. Ball. 1990. Environmental pollution and impacts on soil and forests nutrition in North America. Water, Air, and Soil Pollution 54:3-20.

Kadlec, R. H., and F. B. Bevis. 1990. Wetlands and wastewater: Kinross, Michigan. Wetlands 10:77-92.

Lowrance, R. 1992. Groundwater nitrate and denitrification in a coastal plain riparian forest. Journal of Environmental Quality 21:401-405.

Lowrance, R., R. Todd, J. Fail, Jr., R. Leonard, and L. Asmussen. 1984. Riparian forests as nutrient filters in agricultural watersheds. BioScience 34:374-377.

Malkonen, E. 1990. Estimation of nitrogen saturation on the basis of long-term fertilization experiments. Plant and Soil 128:75-92.

McNulty, S. G., J. D. Aber, T. M. McLellan, and S. M. Katt. 1990. Nitrogen cycling in high elevation forests of the northeastern U.S. in relation to nitrogen deposition. Ambio 19:38-40.

Nihlgard, B. 1985. The ammonium hypothesis-an additional explanation to the forest decline in Europe. Ambio 14:2-8.

Pastor, J., J. D. Aber, and C. A. McClaugherty, 1984. Aboveground production and $\mathrm{N}$ and $\mathrm{P}$ cycling along a mineralization gradient on Blackhawk Island, Wisconsin. Ecology 65:256-268.

Paul, E. A., and F. C. Clark. 1989. Soil microbiology and biochemistry. Academic Press, New York, New York, USA.

Peterjohn, W. T., and D. L. Correll. 1984. Nutrient dynamics in an agricultural watershed: observations on the role of a riparian forest. Ecology 65:1466-1475.

Rascher, C. M., C. T. Driscoll, and N. E. Peters. 1987. Concentration and flux of solutes from snow and forest floor during snowmelt in the west-central Adirondack region of New York. Biogeochemistry 3:209-224.

SAS [SAS Institute]. 1985. SAS user's guide. Version 5. SAS Institute, Cary, North Carolina, USA.

Simmons, R. C., A. J. Gold, and P. M. Groffman. 1992. Nitrate dynamics in riparian forests: groundwater studies. Journal of Environmental Quality 21:656-665.

Skeffington, R. A. 1990 . Accelerated nitrogen inputs-a new problem or a new perspective? Plant and Soil 128:1-11.

Vitousek, P. M., J. R. Gosz, C. G. Grier, J. M. Melillo, and W. A. Reiners. 1982. A comparative analysis of potential nitrification and nitrate mobility in forest ecosystems. Ecological Monographs 52:155-177.

Vitousek, P. M., and R. W. Howarth. 1991. Nitrogen limitation on land and in the sea: how can it occur? Biogeochemistry 13:87-115.

Zak, D. R., K. S. Pregitzer, and G. E. Host. 1986. Landscape variation in nitrogen mineralization and nitrification. Canadian Journal of Forestry 16:1258-1263. 